\title{
Extrahepatic Bile Duct Papillary Neoplasm
}

National Cancer Institute

\section{Source}

National Cancer Institute. Extrahepatic Bile Duct Papillary Neoplasm. NCI Thesaurus. Code C7124.

A non-invasive, papillary epithelial neoplasm that arises from the epithelium of the extrahepatic bile ducts. 